\title{
SISTEM PENGENDALIAN PERSEDIAAAN BAHAN BAKU PADA PERUSAHAAN PENGOLAHAN KARET DI SIDOARJO
}

\author{
Achmad Daengs, GS \\ Universitas 45 Surabaya \\ email : adaengsgs@univ45sby.ac.id \\ Maslikha \\ Universitas 45 Surabaya \\ email : chelika86@gmail.com
}

\begin{abstract}
ABSTRAK
Penelitian ini bertujuan untuk mengetahui sistem pengendalian persediaan bahan baku vulkanisir ban pada perusahaan pengolahan karet Sidoarjo. Sampel yang digunakan adalah target dan realisasi vulkanisir ban selama 5 tahun dan Populasi dari penelitian ini adalah persediaan bahan baku. Data yang digunakan adalah berupa kartu persediaan untuk Tread Crown, Tread Naga Mas, Tread Tiger Dingin dan Compound panas periode tahun 2012. Hasil penelitian ini menunjukkan bahwa model inventory yang paling sederhana tersebut dapat dioptimasikan biaya produksi dan pengendalian persediaan bahan baku. Pada kartu persediaan yang diperoleh dari perusahaan terdapat stock yang kurang yang menjadi perhatian khusus bagi perusahaan, hal ini dikarenakan perusahaan kurang tepat dalam memperhitungkan jumlah bahan baku yang dipakai sehingga persediaan bahan baku kurang optimal. Setelah dianalisis langkah pemecahannya dilakukan dengan menentukan safety stock sebagai persediaan pengaman, Reorder Point sebagai pemesanan kembali, Economic Order Quantity sebagai pemesanan secara ekonomis, dan Maksimum Inventory sebagai persediaan yang maksimum di gudang. Saran peneliti dengan model ini menunjukan hasil bahwa dengan pengendalian bahan baku, stock tidak akan kekurangan atau kehabisan maupun kelebihan bahan baku, sehingga proses produksi bisa berjalan lancar dan tidak terjadi kerusakan akibat penumpukan bahan baku, dan mengurangi biaya produksi.
\end{abstract}

Kata kunci : Pengendalian, Safety Stock, Reorder Point, Economic Order Quantity, Maksimum Inventory.

\section{Pendahuluan}

Dalam era globalisasi dan menjelang era perdagangan bebas, pemerintah telah melaksanakan pembangunan di segala bidang terutama di bidang ekonomi untuk memenuhi kebutuhan penduduk yang makin meningkat dan bertambah. Dampak globalisasi pada bidang perekonomian menyebabkan persaingan antar perusahaan menjadi semakin ketat, persaingan yang semakin ketat ini menuntut fundamental manajemen sehingga akan mampu bersaing dengan perusahaan lain. 
Suatu perusahaan didirikan pasti mempunyai suatu tujuan yaitu untuk dapat berjalan secara terus-menerus atas usaha yang didirikannya. Dalam hal ini, yang perlu diperhatikan untuk menjaga kelangsungan hidup dari suatu perusahaan adalah persediaan bahan baku, karena persediaan bahan baku merupakan salah satu faktor yang terpenting dalam menjaga kelangsungan proses produksi.

Persediaan bahan baku merupakan salah satu elemen aktiva lancar yang aktif dan selalu berhubungan erat dalam setiap proses produksi misalnya, mulai dari dibelinya bahan baku tersebut, diproduksi, dan dijual ke konsumen hingga setiap akhir periode jumlah persediaan dapat ditentukan secara tepat dan benar. Apabila terjadi kekeliruan dalam penentuan persediaan maka akan dapat menimbulkan kerugian.

Dalam perusahaan atau industri pada umumnya ada 3 jenis persediaan yaitu:

1. Persediaan bahan baku

2. Persediaan barang dalam proses

3. Persediaan barang jadi

Didalam penyediaan bahan baku biasanya didasarkan dari pengalaman pengalaman perusahaan yang lalu. Sedangkan persediaan yang paling likuid adalah persediaan barang jadi, karena persediaan barang jadi adalah hasil proses produksi akhir yang akan dijual ke konsumen sehingga dapat dijadikan modal untuk membeli bahan baku tersebut.

Seperti yang kita ketahui bersama, bahwa pada umumnya persediaan bahan baku dibeli apabila persediaan di gudang mulai menipis atau telah digunakan dalam proses produksi. Untuk perusahaan yang kecil, pemilik biasanya melakukan segala sesuatunya dengan sendiri mulai dari penjualan, pembelian, perhitungan persediaan bahan baku. Salah satu sumber daya yang dimiliki oleh perusahaan industri untuk memperoleh bahan baku yang diinginkan perusahaan tersebut pada umumnya untuk menentukan sejumlah persediaan bahan baku yang optimal dan uang merupakan suatu investasi pada persediaan bahan baku tersebut.

\section{Kajian Pustaka}

Dalam kegiatan persediaan bahan baku di perusahaan merupakan suatu unsur penting dalam pengendalian yang akan diperlukan oleh pimpinan perusahaan untuk memungkinkan apabila pimpinan akan mengadakan suatu pengawasan terhadap masalah-masalah yang berhubungan dengan kegiatan persediaan bahan baku tersebut.

Controlling sering diterjemahkan dengan kata pengendalian dan pengawasan. Kedua istilah ini sering kali penggunaanya dipertukarkan terutama di lingkungan dunia usaha. Pengendalian didefinisikan sebagai hubungan antara prosedur dan sistem yang berkaitan dengan pencapaian tujuan perusahaan. Kemampuan menghasilkan dari suatu jenis sumber daya tergantung kepada baik tidaknya pengelolaan dari berbagai jenis sumber daya yang digunakan di dalam kegiatan pengelolaan atau produksi Dalam hal ini, bagian produksi perusahaan bertanggung jawab atas kegiatan-kegiatan pembelian, pengadaan bahan baku dan bahan pembantu, penciptaan dan pemeliharaan mutu, termasuk rekayasa dan pembuatan program yang berkaitan. (Sumarsan, 2010:5). 
Apabila kita memperhatikan pengendalian dari waktu ke waktu maka terlihat adanya suatu perkembangan dalam suatu pengertian, mulai perkembangan yang sempit sampai perkembangan yang luas.

Dalam arti yang sempit istilah tersebut disamakan dengan Check yang merupakan prosedur-prosedur mekanis untuk memeriksa ketelitian dari data-data seperti mencocokkan penjumlahan mendatar ( horizontal) dengan penjumlahan melurus (vertikal). Sedangkan menurut BuIIetin American Institue Of Account, sekarang diganti dengan American Institute Of Certified Public Account s yang di maksud dengan check adalah suatu alat dalam bidang pembukuan di mana dapat diperoleh bukti ketelitian dari angka melalui orang yang berbeda dengan hasil yang sama. (Kusuma, 2001:45 )

\section{Pentingnya Pengendalian}

Suatu perusahaan, baik besar maupun kecil sebaiknya mempunyai pengendalian. Agar memahami lebih jelasnya penulis memberikan gambaran, di dalam suatu perusahaan terdiri dari seorang pemimpin dan dua orang pembantu, segala kegiatan yang dilakukan oleh para pembantu masih dapat secara langsung di ikuti dan di awasi oleh pimpinan. Kalau perusahaan berkembang dalam kegiatan dan jumlah pembantu, makin kecil kemampuan pemimpin untuk mengendalikan sesuatu yang terjadi dalam perusahaan, keadaan semacam ini memaksanya melimpahkan sebagian wewenangnya kepada bawahannya tapi tanggung jawab tetap ada pada tangan pemimpin oleh sebab itu ia memerlukan suatu sistem pengendalian yang dapat mengamankan aktiva perusahaan, yang memberikan keyakinan padanya bahwa apa yang dilaporkan bawahannya itu benar dan dapat dipercaya, yang dapat mendorong adanya efesiensi usaha dan dapat terus-menerus memonitor bahwa kebijaksanaan yang telah di tetapkan memang di jalankannya.

\section{Karakteristik Pengendalian Yang Baik}

Suatu sistem yang baik untuk suatu perusahaan belum tentu baik untuk perusahaan yang lain, meskipun kedua perusahaan tersebut termasuk perusahaan yang sejenis.

Jenis usaha dan ukuran perusahaan yang sama dapat mensyaratkan adanya sistem pengendalian yang berlainan, misal karena yang keahlian dan filsafat pimpinan perusahaan yang berbeda atau karena keahlian dan tingkat dapat dipercayainya pegawai ke dua perusahaan tersebut berbeda.

Secara umum dapat dikatakan bahwa suatu sistem pengendalian adalah baik jika tidak seorangpun berada dalam kedudukan sedemikian rupa sehingga ia dapat membuat kesalahan dan meneruskan tindakan yang tidak diinginkan tanpa diketahui dalam waktu yang terlalu lama.

Supaya sistem ini dapat berjalan dengan baik sesuai prosedur yang dapat memberikan isyarat tentang terjadinya keganjilan dalam sistem pertanggung jawaban atas transaksi atau kekayaan yang di kuasakan kepadanya. (Nasution, 2003:9) 


\section{Sistem dan Prosedur}

Pimpinan perusahaan berkepentingan untuk mengetahui keadaan dalam perusahaan yang sedang dipimpin. Dalam perusahaan kecil pimpinan dapat secara langsung turun tangan mengawasi pekerjaan setiap bagian dan dapat mengetahui kedaan perusahaan secara langsung pula, apabila perusahaan sudah berkembang menjadi besar, dimana sebagian tugas dan wewenang pimpinan dapat didelegasikan kepada orang lain, pimpinan perusahaan membutuhkan alat untuk mengadakan suatu pengawasan dan mengetahui kemajuan yang telah dicapai. Kebutuhan ini dapat dipenuhi dengan adanya sistem dan prosedur yang telah di rencanakan dengan baik.

Definisi dari sistem dan prosedur tersebut adalah: ( Nasution, 2003:104 )

"System is a network of related procedure developed according to one integrated scheme for performing a mayor activity of business".

"Sistem adalah jaringan prosedur yang erat hubungan antara satu sama lain, yang disusun menjadi satu kesatuan untuk melaksanakan aktivitas utama perusahaan".

"A procedure is sequence of clerical operation, usually involving several people in one or more departments, establisted to ensure uniform handling of a recurring transaction of business".

"Prosedur adalah suatu urutan pekerjaan yang biasanya melibatkan beberapa orang dalam satu bagian atau lebih disusun untuk menjamin adanya perlakuan yang seragam terhadap transaksi-transaksi di perusahaan yang sering terjadi.

\section{Persediaan}

Pada setiap perusahaan baik perusahaan dagang maupun perusahaan industri senantiasa selalu mengadakan persediaan. Tanpa adanya persediaan para pengusaha akan menghadapi satu resiko, bahwa perusahaan pada suatu saat tidak mempengaruhi keinginan para pelanggan atau konsumen yang memerlukan dari barang yang dihasilkan jadi persediaan sangat penting artinya untuk setiap perusahaan yang menghasilkan barang atau jasa.

Sedangkan persediaan adalah kekayaan lancar yang terdapat di perusahaan dalam bentuk persediaan bahan mentah, barang setengah jadi, dan barang jadi ( Prawirosentono, 2007:65).

Persediaan merupakan salah satu unsur aktiva lancar yang dilikuiditasnya paling rendah. Selain itu ada kemungkinan persediaan mengalami kerusakan atau keausan sehingga nilainya menjadi turun. Persediaan memiliki arti sangat penting bagi dalam operasi bisnis suatu perusahaan, guna memenuhi kebutuhan produksi dan memberikan kepuasan pada kebutuhan organisasi. (Sudana, 2011:226 ).

Adapun alasannya di perlukan persediaan oleh suatu perusahaan adalah : (Sumarsan, 2010:176).

1. Dibutuhkan waktu untuk menyesuaikan operasi produksi dan untuk memindahkan produksi dari satu tingkat ke tingkat lain, yang disebut persediaan dalam proses

2. Alasan organisasi untuk memungkinkan bagian membuat schedule operasinya secara bebas tidak tergantung dari yang lain.

Sedangkan persediaan yang diadakan mulai dari bentuk bahan mentah sampai dengan barang jadi antara lain berguna untuk : ( Sumarsan, 2010:177 ) 
1. Menghilangkan resiko keterlambatan datangnya bahan baku yang dibutuhkan perusahaan.

2. Menghilangkan resiko dari material yang dipesan tidak baik sehingga harus dikembalikan.

3. Untuk menumpuk bahan yang telah dihasilkan secara musiman, sehingga dapat digunakan bila bahan itu tidak ada.

4. Mempertahankan stabilitas operasi perusahaan atau menjamin kelancaran arus produksi.

5. Mencapai penggunaan mesin yang optimal.

6. Memberikan pelayanan kepada pelanggan dengan sebaik-baiknya.

7. Membuat pengadaan atau produksi tidak perlu sesuai dengan penggusaanya atau penjualannya.

Pada uraian diatas terlihat bahwa persediaan, memegang peranan yang penting sekali bagi suatu perusahaan, karena fungsi yang diberikan yaitu menghubungkan antara operasi yang berurutan dalam pembuatan suatu barang dan menyampaikan kepada pelanggan Persediaan dapat diminimumkan dengan mengadakan perencanaan produksi yang lebih baik, serta organisasi pengawasan pengendalian yang lebih baik pula. Masalah penentuan investasi dalam persediaan merupakan masalah yang penting dalam perusahaan, karena persediaan mempunyai efek langsung terhadap keuntungan yang diperoleh perusahaan. Kesalahan dalam menetapkan besarnya ini bukanlah berarti invetasi dalam persediaan harus benar jumlahnya atau harus sedemikian kecilnya, melainkan investasi ini juga harus di atur secara efesien. Investasi yang terlalu besar dalam persediaan di bandingkan dengan kebutuhan akan memperbesar beban bunga, biaya penyimpanan dan pemeliharaan di gudang dan juga memperbesar kemungkinan karena kerusakan turun kualitas, dan lain sebagainya. Sehingga semua ini memperkecil keuntungan perusahaan tetapi sebaliknya bila investasi dalam perusahaan terlalu kecil juga akan menekan keuntungan karena kekurangan material perusahaan tidak dapat bekerja dengan kapasitas yang optimal.

Pengertian inventory atau persediaan adalah bahwa dapat di jelaskan persediaan memang merupakan atau bagian utama elemen utama dari modal kerja untuk melakukan kegiatan atau aktivitas utama dalam suatu perusahaan dimana aktiva tersebut harus selalu berputar tidak boleh berhenti dan juga harus terus menerus mengalami perubahan-perubahan. Jika aktiva tersebut sampai terhenti secara total, maka dengan itu kita harus berusaha agar aktivitas tersebut selalu tetap berputar di mana juga harus terus menerus mengalami perubahan-perubahan. (Nasution, 2003:108).

\section{Metode Pencatatan Persediaan Bahan Baku}

Catatan di atas persediaan bahan baku dengan tujuan mengawasi barang, mempunyai metode pencatatan yaitu: ( Prawirosentono, 2007:73 )

1. Metode persediaan periodik atau fisik

Suatu sistem persediaan periodik memerlukan investasi fisik yaitu suatu perhitungan, pengukuran atau penyeimbangan barang, pada akhir periode akuntansi untuk menetapkan kuantitas yang ada dalam perusahaan. Nilainilainya kemudian diletakkan pada kuantitas-kuantitas yang ada untuk 
menetapkan bagian harga pokok tercatat yang di bawa ke masa yang akan datang.

2. Metode persediaan perpetual atau permanen.

Sistem persediaan perpetual memerlukan pengelolahan catatan yang menyajikan suatu ikhtisar yang kontinyu atas pos-pos persediaan yang ada dalam perusahaan. Perkiraan individu di buat menurut masing-masing kelompok persediaan.

Dalam metode perpetual ini masing-masing jenis persediaan di buatkan suatu rekening tersendiri penambahan barang karena pembelian barang akan di catat pada sebelah debet rekening dan setiap kali terjadi pengeluaran barang untuk proses produksi harus di buat ayat jurnal untuk mencatat harga pokok barang tersebut. Untuk tujuan pengendalian barang, sebenarnya metode persediaan perpetual ini lebih menguntungkan.

\section{Penilaian Persediaan Bahan Baku Berdasarkan Harga Pokok}

Kadangkala dalam perusahaan, untuk jenis barang yang sama dalam suatu periode tertentu telah dibeli dengan harga satuan yang berbeda. Sehingga pada akhir periode akan timbul masalah dalam menentukan besarnya harga pokok produksi barang, serta jumlah persediaan barang yang akan dilaporkan sebagai persediaan akhir dalam neraca.

Secara umum ada tiga metode atau cara dalam menentukan harga pokok bahan baku, yaitu: ( Kostas, 2008:44 )

1. Metode FIFO (First In First Out)

Untuk menetapkan harga pokok persediaan didasarkan atas asumsi bahwa harga pokok harus dibebankan atas harga pokok dari persediaan sesuai dengan urutan pembelian barang.

2. Metode UFO (Last In First Out)

Untuk menetapkan harga pokok persediaan didasarkan atas asumsi bahwa harga pokok produksi barang harus di bebankan atas harga pokok dari persediaan, sesuai dengan pembelian terakhir barang.

3. Metode Average

Didasarkan atas asumsi bahwa harga pokok yang dibebankan ke harga pokok produksi adalah harga rata-rata per unit dari barang yang di jual.

Besar kecilnya persediaan bahan mentah dipengaruhi oleh beberapa faktor antara lain sebagai berikut:

a. Jumlah bahan mentah yang dibutuhkan untuk melindungi perusahaan terhadap gangguan kehabisan bahan mentah

b. Volume produksi yang di rencanakan

c. Jumlah setiap kali pembelian untuk mendapatkan ongkos minimal

d. Harga pembelian bahan mentah

e. Penyimpanan dan resiko

f. Kecepatan bahan mentah menjadi rusak atau turunnya kualitas

g. Kebijaksanaan pembelanjaan yaitu kebijaksanaan yang berhubungan dengan perencanaan penentuan jumlah dana yang tersedia 


\section{Faktor-Faktor Persediaan}

Meskipun persediaan akan memberikan banyak manfaat bagi perusahaan, namun perusahaan tetap hati-hati dalam menetukan kebijakan persediaanpersediaan membutuhkan biaya investasi dan dalam hal ini menjadi tugas bagi manajemen untuk menentukan investasi yang optimal dalam persediaan. Masalah persediaaan merupakan masalah pembelanjaan aktif, dimana perusahaan menggunakan dana yang dimiliki dalam persediaan dengan cara yang efektif. Untuk melangsungkan usahanya dengan lancar maka kebanyakan perusahaan merasakan perlunya persediaan. Faktor yang mempengaruhi jumlah persediaan adalah:

1. Perkiraan pemakaian bahan baku

Penentuan besarnya persediaan bahan yang diperlukan harus sesuai dengan kebutuhan pemakaian bahan tersebut dalam satu periode tertentu. Untuk memperoleh perencanaan yang realistis harus memperhitungkan pengalamanpengalaman sebelumnya. Pemakaian bahan baku senyatanya dari periode yang lalu ( (actual demand) merupakan salah satu faktor yang perlu di perhatikan seberapa besar penyerapan bahan baku oleh proses produksi perusahaan serta bagaimana bubungan dengan perkiraan pemakaian yang sudah di susun harus senantiasa di analisa.

2. Harga bahan baku

Harga bahan yang diperlukan merupakan faktor lainnya yang dapat mempengaruhi besarnya persediaan yang harus diadakan. Harga bahan baku ini merupakan dasar penyusunan perhitungan berapa besar dana perusahaan yang harus di sediakan untuk investasi dalam persediaan bahan baku ini, maka biaya modal ( cost of capital) yang dipergunakan dalam persediaan bahan baku tersebut harus pula diperhitungkan. Didalam perhitungan biaya yaitu biaya yang semakin besar dengan semakin besarnya rata-rata persediaan, serta biaya yang justru semakin kecil dengan semakin kecilnya rata-rata persediaan. Seberapa besar persediaan bahan baku yang terdapat dalam perusahaan akan tergantung kebijaksanaan pembelanjaan dari dalam perusahaan, kapan dan berupa bahan baku tersebut di beli dan kapan akan mengadakan pembelian kembali, jadi dalam hal ini perusahaan perlu memilih kebijaksanaan pembelanjaan yang tepat bagi persediaan bahan baku. Di samping itu juga dilihat dana yang telah disediakan tersebut cukup untuk pembayaran semua bahan yang diperlukan perusahaan, atau hanya sebagian saja.

3. Biaya persediaan

Terdapat beberapa jenis biaya untuk menyelenggarakan persediaan bahan baku, adapun jenis biaya persediaan adalah biaya pemesanan (order cost) dan biaya penyimpanan bahan di gudang.

4. Waktu menunggu pesanan (lead time)

Adalah waktu antara tenggang waktu sejak pesanan dilakukan sampai dengan saat pesanan tersebut masuk ke gudang. Waktu tunggu sangat perlu diperhatikan oleh karena itu sangat erat hubungan dengan penentuan saat 
pesanan kembali (reorder point). Dengan diketahui waktu tunggu yang tepat, maka perusahaan akan dapat membeli pada saat yang tepat pula, sehingga penumpukan persediaan atau kekurangan persediaan dapat ditekan seminimal mungkin.

Dengan demikian kebijaksanaan persediaan bahan baku yang tepat akan mendasarkan diri kepada faktor tersebut. Oleh karena itu dengan di ketahuinya kebijaksanaan pembelanjaan (financial policy), biaya-biaya persediaan harga adapun hubungan dari masing-masing faktor tersebut di atas adalah sebagai berikut:

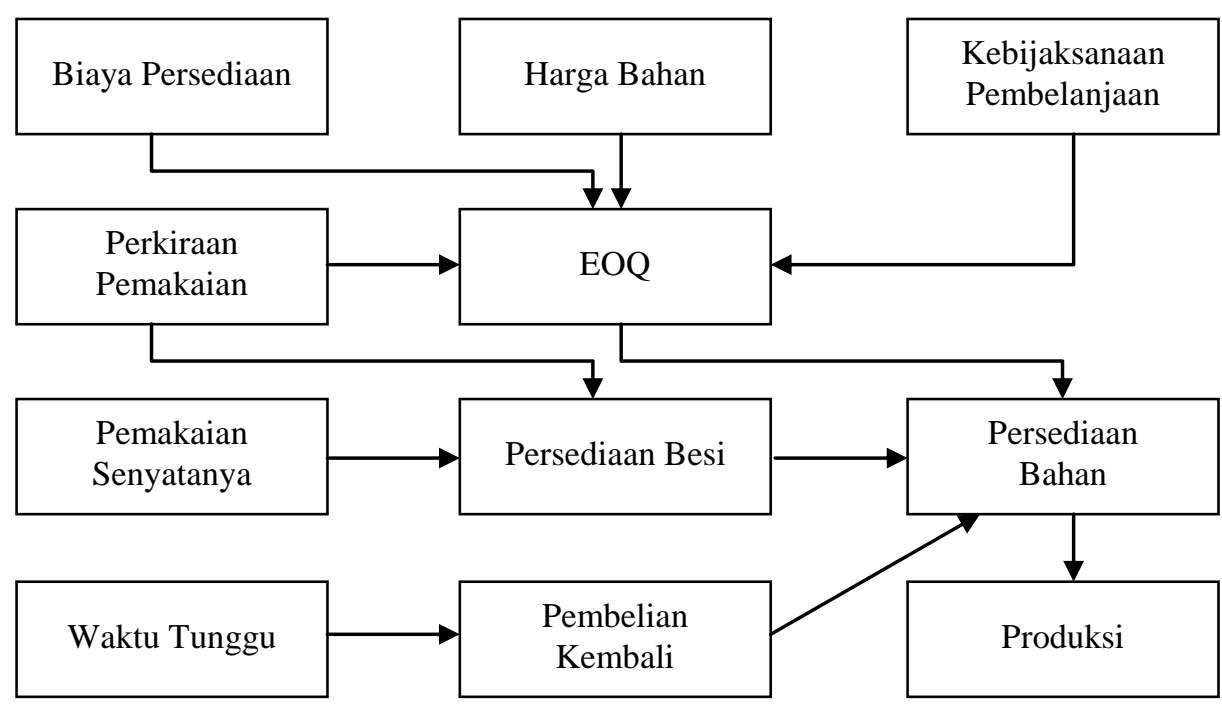

Sumber: Assauri, 2004

\section{Gambar 1}

\section{Faktor-faktor yang mempengaruhi persediaan bahan baku}

Daripada bahan serta perkiraan pemakaian bahan baku, akan dapat pula ditentukan secara ekonomis dengan diketahui perkiraan pemakaian dan pemakaian yang sesungguhnya ( pada waktu lalu ) akan dapat pula di analisa jumlah persediaan besi (safety stock) yang paling tepat, serta waktu tunggu yang di gunakan untuk menetapkan waktu pesanan kembali ( reorder point ).

Jadi EOQ, Safety stock. Reorder point akan membentuk suatu pola persediaan bahan baku dari perusahaan yang bersangkutan. Dari uraian di atas dapat di simpulkan bahwa dengan adanya faktor-faktor tersebut akan membentuk suatu sistem pengawasan persediaan yang efektif dan efesien, sehingga akan menjadi kontinuitas proses produksi bagi perusahaan yang bersangkutan.

\section{Metode dan Aktivitas Pengendalian Persediaan}

Untuk perusahaan harus mempunyai kebijaksanaan dalam pengaturan pengawasan persediaan, baik cara pemesanan maupun jumlah yang dipesan tersebut ekonomis, ada beberapa cara yaitu, jumlah pesanan yang Economic 
Order Quantity ( $E O Q$ ). Yang maksudnya adalah EOQ merupakan volume atau jumlah pembelian yang paling ekonomis untuk dilaksanakan pada setiap kali pembelian. Sedangkan yang dimaksud dengan pesanan yang paling ekonomis di sini yaitu bahwa jumlah atau besarnya pesanan diadakan hendaknya menghasilkan biaya-biaya yang timbul dalam penyediaan adalah minimal data dengan kata lain jumlah pesanan yang di sertai dengan jumlah biaya yang paling rendah atau murah.

Syarat yang perlu diperhatikan dalam Economic Order Quantity (EOQ):

1. Jumlah permintaan diketahui, konstan, dan independen.

2. Waktu tunggu yakni waktu antara pemesanan dan penerimaan pesanan diketahui dan konstan.

3. Penerimaan persediaan bersifat instan dan selesai seluruhnya. Dengan kata lain, persediaan dari sebuah pesanan datang dalam satu kelompok pada suatu waktu.

4. Tidak tersedia diskon kuantitas.

5. Biaya variabel hanya biaya untuk menyiapkan atau melakukan pemesanan ( biaya penyetelan ) dan biaya menyimpan persediaan dalam waktu tertentu ( biaya penyimpanan atau membawa).

6. Kehabisan persediaan ( kekurangan persediaan ) dapat sepenuhnya dihindari jika pemesanan dilakukan pada waktu yang tepat.

Disamping itu sebelum bahan dasar habis terpakai harus sudah dilakukan pesanan kembali. Titik dimana harus dilakukan kembali pesanan disebut "Reorder Point" $(R O P)$. Terdapat beberapa yang perlu diperhatikan dalam menentukan titik pemesanan kembali, yakni sebagai berikut :

1. Sebuah perusahaan akan menempatkan sebuah pesanan ketika tingkat persediaannya untuk barang tertentu tersebut mencapai nol dan

2. Perusahaan akan menerima barang yang dipesan secara langsung, disebut waktu tunggu ( lead time) atau waktu pengantaran, bisa jadi hanya beberapa jam atau bisa juga mencapai beberapa bulan.

Oleh karena itu dalam menghitung biaya Economic Order Quantity (EOQ) haruslah diperhitungkan biaya sebagai berikut:

1. Biaya Pemesanan

Adalah biaya yang dikeluarkan tiap kali pesan. Biaya pemesanan akan semakin kecil bila bahan yang dipesan semakin banyak jumlahnya. Sebaliknya biaya, pemesanan per unit akan makin besar bila jumlah pesananya makin kecil. Biaya pesanan atau ordering cost sebagai berikut:

Biaya yang dikeluarkan untuk memesan bahan tersebut,

Biaya pengiriman barang pesanan,

Biaya penerimaan bahan yang di pesan

2. Biaya Penyimpanan

Adalah biaya yang dikeluarkan akibat perusahaan menyimpan bahan di gudang. Biaya penyimpanan biasa dinyatakan dalam persentase tertentu dari nilai persediaan. Total biaya penyimpanan persediaan dalam satu tahun merupakan persentase biaya penyimpanan persediaan dikali harga beli persediaan dikali rata-rata jumlah persediaan. 
Dengan demikian semakin banyak jumlah persediaan, semakin besar biaya penyimpanan dan sebaliknya. Biaya penyimpanan ini menurut ( Assauri, 2004:186) terdiri dari:

Biaya pemeliharaan bahan

Biaya sewa gudang

Biaya asuransi

Biaya obsolescence ( kerusakan bahan karena disimpan di gudang)

Bunga modal (interest - rate)

Biaya pajak persediaan bahan yang ada dalam gudang.

3. Biaya lead time

Yaitu waktu yang dibutuhkan sejak memesan barang yang dipesan tersebut datang. Sedangkan dapat ditentukan dengan cara menentukan jumlah penggunaan selama lead time dan di tambah dengan besarnya safety stock

4. Jumlah Persediaan Besi

Yaitu dimaksud dengan persediaan besi adalah persediaan minimal bahan mentah yang harus di pertahankan untuk menjamin kelangsungan proses produksi. Persediaan besi merupakan sejumlah bahan sebagai persediaan cadangan kaku perusahaan berproduksi melebihi rencana yang telah di tentukan. Untuk menjaga agar kelancaran proses produksi tidak terganggu yang disebabkan karena keterlambatan pesanan tiba, maka diperlukan safety stock ( persediaan pengaman ), persediaan bahan mentah masih berada diatas safety stock.

Terdapat 2 (dua) hal pokok yang perlu diperhatikan dalam menentukan cadangan penyelamat, yakni sebagai berikut :

a. Besar/kecilnya kemungkinan terjadinya kehabisan bahan

b. Besar/kecilnya atau sulit dan mudahnya memperoleh bahan-bahan pengganti secara tepat dan cepat. Artinya, apabila kemungkinan terjadinya stock out besar namun, dapat diantisipasi dengan upaya pengadaan darurat secara mudah dan cepat,belum tentu perlu cadangan penyelamat.

Dengan demikian cadangan ini merupakan pengaman agar proses produksi tidak terganggu yang disebabkan adanya ketidak pastian jumlah penggunaan bahan. Persediaan besi ini merupakan simpanan bahan yang jumlahnya selama jangka waktu tertentu.

5. Jumlah Persediaan Maksimum

Persediaan maksimum merupakan batas jumlah persediaan yang paling besar yang dapat diadakan oleh perusahaan. Dalam menentukan persediaan maksimum harus didasarkan atas pertimbangan ekonomis pula agar dapat diperoleh persediaan yang optimum hal ini berguna agar perusahaan tidak akan mengalami kerugian yang akan timbul. Jika dapat diketahui besarnya persediaan maksimum, akan dapat pula membantu besarnya investasi maksimum yang perlu disediakan untuk barang yang dibutuhkan.

Salah satu cara dalam menentukan jumlah maksimum inventory adalah dengan menghitung terlebih dahulu Economic Order Ouantitynya, selanjutnya ditambah dengan safety stock. ( Assauri, 2004:186 )

Dengan rumus:

Maksimum Inventory $=E O Q+$ Safety Stock 


$$
\begin{aligned}
& \text { Safety Stock } \quad=\mathrm{SS}=\mathrm{K} \sqrt{\overline{\mathrm{L}} \mathrm{x}(\mathrm{SD})^{2}+\overline{\mathrm{D}}^{2} \mathrm{x}(\mathrm{SL})^{2}} \\
& S D=\frac{\sqrt{\sum(D-\bar{D})^{2}}}{n-1} S L=\frac{\sqrt{\sum(L-\bar{L})^{2}}}{n-1}
\end{aligned}
$$

Jadi melalui ini perusahaan dapat mengetahui perkembangan persediaan dalam gudang secara mudah dan cepat setiap saat.

\section{Metode Penelitian}

Tujuan diadakannya penelitian adalah untuk meneliti pada populasi atau sampel tertentu, pengumpulan data menggunakan instrumen penelitian, analisis data yang bersifat kuantitatif, maka rumusan penelitian perlu disesuaikan dengan tujuan penelitian tersebut. (Sugiyono, 2012:59)

Dalam penelitian ini, peneliti ingin mengetahui gambaran yang jelas tentang persediaan bahan baku PT. Surya Mas Agung dengan objek penelitian vulkanisir ban. Peneliti ingin melihat bagaimana pengendalian persediaan bahan baku. maka tipe penelitian yang dipergunakan adalah deskriptif kuantitatif, penelitian tipe deskriptif kuantitatif ini tidak hanya sekedar menggambarkan realitas yang diteliti, tetapi juga memberikan dasar penarikan kesimpulan dengan data berupa angka. Oleh karena itu, dalam penelitian ini konsep-konsep yang dipilih bukan untuk dikaji, tetapi dipergunakan sebagai alat bantu untuk menginterpretasikan hakekat suatu gejala atau realitas yang diteliti ( Moleong, 2000:74).

Untuk memberikan pembahasan yang terarah dalam penelitian ini, maka perlu diberikan batasan penelitian. Batasan penelitian dilakukan pada persediaan bahan baku yang ada di perusahaan pengolahan karet.

Untuk kepentingan penggalian data penelitian, variabel penelitian harus dibuat definisi operasionalnya. Berikut adalah definisi operasional dari variabelvariabel yang menjadi dasar pengukuran :

1. Safety stock merupakan pengaman agar proses produksi tidak terganggu yang disebabkan adanya ketidak pastian jumlah penggunaan bahan.

2. Reorder Point merupakan. Titik di mana harus dilakukan pemesanan kembali.

3. Economic Order Quantity merupakan volume atau jumlah pembelian yang paling ekonomis untuk dilaksanakan pada setiap kali pembelian.

4. Ordering Cost ( Biaya Pemesanan) merupakan biaya yang dikeluarkan tiap kali pesan.

5. Biaya Penyimpanan merupakan biaya yang dikeluarkan akibat perusahaan menyimpan bahan di gudang. 
6. Biaya Lead time merupakan waktu yang dibutuhkan sejak memesan barang yang dipesan tersebut datang.

7. Iron Stock (Jumlah Persediaan Besi ) merupakan persediaan minimal bahan mentah yang harus di pertahankan untuk menjamin kelangsungan proses produksi.

8. Inventory maximum ( Jumlah Persediaan Maksimum ) merupakan batas jumlah persediaan yang paling besar yang dapat diadakan oleh perusahaan

\section{Teknik Analisis Data}

Analisa dengan metode kuantitatif dengan menggunakan model-model tertentu sesuai dengan tujuan penelitian. Pada dasarnya analisis data adalah kegiatan untuk memanfaatkan data. Maksud dan tujuan dari analisis data adalah untuk menguji dan untuk membuktikan benar tidaknya teknik yang dilakukan. Data dikumpulkan, dianalisa secara sistematis, kemudian menerapkan hasil dari analisis data tersebut.

Menurut ( Assauri, 2004:186 ) adapun teknik analisis yang digunakan oleh penulis adalah sebagai berikut:

1. Menentukan Safety Stock

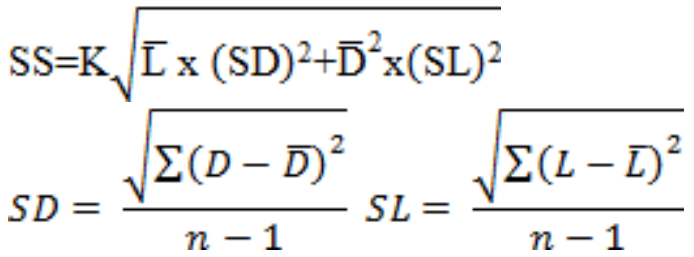

Dimana:

$\mathrm{K}=\quad$ Level of Service

$\mathrm{L}=\quad$ Lead Time

$\overline{\mathrm{L}}=\quad$ Lead time rata-rata

$\mathrm{D}=\quad$ Penggunaan bahan/hari

$\overline{\mathrm{D}}=\quad$ Penggunaan bahan rata-rata/hari

$\mathrm{SL}=\quad$ Standart deviasi lead time

SD $=$ Standart deviasi penggunaan bahan

2. Menentukan ROP (Re Order Point)

$R O P=(\mathrm{D} \times \mathrm{L})+\mathrm{SS}$

Dimana:

$\mathrm{L}=\quad$ Lead time rata-rata

$\mathrm{D}=$ Kebutuhan rata-rata/hari

$\mathrm{S} \mathrm{S} \quad=\quad$ Safety Stock

3. Menentukan EOQ (Economic Order Quantity)

$E O Q=\sqrt{\frac{2 \mathrm{x} \mathrm{R} \mathrm{S}}{\mathrm{P} \times 1}}$

Dimana:

$\mathrm{R}=\quad$ kebutuhan bahan baku selama satu periode

$\mathrm{S}=$ biaya pemesanan setiap kali pesan

$\mathrm{L}=\quad$ biaya penyimpanan dan pemeliharaan di gudang dalam $\%$ 
$\mathrm{P}=$ harga pembelian per unit yang harus di bayar

Frekuensi Pembelian Bahan Baku sebagai berikut:

$F=\frac{\mathrm{R}}{\mathrm{EOQ}}$

Dimana:

$\mathrm{F}=$ frekuensi pembelian

$\mathrm{R}=\quad$ kebutuhan bahan baku dalam 1 tahun

$E O Q=$ jumlah pesanan yang ekonomis

4. Menentukan Jumlah Persediaan Maksimum

$\mathrm{MI}=\mathrm{SS}+E O Q$

Dimana:

$\mathrm{MI}=\quad$ persediaan maksimum

$\mathrm{SS}=\quad$ Safety Stock

$E O Q=$ jumlah pesanan yang ekonomis

\section{Analisis Data dan Pembahasan}

Perusahaan dalam melaksanakan proses produksi sering mengalami hambatan karena perusahaan sering mengalami stock out sehingga proses produksi terhenti, hal ini disebabkan karena perusahaan tidak menggunakan metode pengendalian persediaan yang tepat.

Dalam pengadaan bahan baku perusahaan tidak berdasarkan pada rumusrumus atau kebijakan standart. Dalam melakukan pembelian bahan baku hanya berdasarkan catatan-catatan pembelian yang lalu dan juga berdasarkan pengalaman pada tahun-tahun sebelumnya.

\section{Kesimpulan}

1. Permasalahan yang terjadi di perusahaan yaitu persediaan bahan baku yang tidak optimal sehingga mengganggu proses produksi akibat kekurangan bahan baku. Hal ini disebabkan karena perusahaan belum menggunakan pengendalian persediaan bahan baku secara tepat, di mana perusahaan dalam pengendalian persediaan bahan baku tidak di rencanakan serta diperhitungkan berdasarkan metode Inventory Control tetapi berdasarkan catatan-catatan dan pengalaman masa lalu.

2. Untuk mengatasi masalah yang di hadapi tersebut maka dapat diajukan langkah-langkah pemecahan sebagai berikut:

- Menentukan besarnya Safety Stock

Dengan ditetapkannya jumlah persediaan pengaman yang ada di dalam gudang tread Crown sebesar $1086 \mathrm{~kg}$, tread Naga Mas sebesar $212 \mathrm{~kg}$, tread Tiger Dingin sebesar $539 \mathrm{~kg}$, dan compound ( panas ) sebesar 704 $\mathrm{kg}$, maka kekurangan persediaan bahan baku dapat diatasi.

- Menentukan Reorder Point

Dengan ditentukannya Reorder Point, maka pembelian bahan baku akan teratur dan pasti. Berdasarkan pembahasan yang telah di bahas pada bab sebelumnya maka reorder point di tetapkan untuk tread Crown sebesar $7470 \mathrm{~kg}$, tread Naga Mas sebesar $1122 \mathrm{~kg}$, tread Tiger Dingin sebesar $2835 \mathrm{~kg}$ dan compound ( panas ) sebesar $3630 \mathrm{~kg}$, hal ini berarti persediaan yang ada di gudang maka harus segera dilakukan pemesanan kembali sehingga apabila persediaan sudah mencapai sebesar safety stock, 
maka persediaan sudah datang dengan demikian perusahaan tidak akan mengalami kekurangan persediaan bahan baku dan proses produksi dapat berjalan lancar.

- Menentukan besarnya Economic Order Quantity

Dari perhitungan yang telah dilakukan maka dapat ditentukan besarnya jumlah pesanan yang ekonomis namun tidak mengaggu proses produksi yaitu untuk tread Crown sebesar 18218 kg. tread Naga Mas sebesar 6917 $\mathrm{kg}$, tread Tiger Dingin sebesar $11508 \mathrm{~kg}$ dan compound ( panas ) sebesar $14319 \mathrm{~kg}$ tiap kali pesan.

- Menentukan besarnya Maksimum Inventory

Dengan ditentukannya persediaan maksimum untuk tread Crown sebesar $19304 \mathrm{~kg}$, tread Naga Mas sebesar 7129 kg, tread Tiger Dingin sebesar $12047 \mathrm{~kg}$ dan compound ( panas ) sebesar $15023 \mathrm{~kg}$, maka perasahaan tidak akan kelebihan persediaan bahan baku, sehingga akan terhindar dari penumpukan bahan baku di gudang dan resiko kerusakan bahan baku.

- Dengan menggunakan pengendalian persediaan bahan baku maka dapat diketahui frekuensi pembelian baku yang efesien adalah untuk tread Crown sebanyak 7 kali, tread Naga Mas sebanyak 3 kali, tread Tiger Dingin sebanyak 4 kali, dan Compound (panas) sebanyak 4 kali.

3. Dari hasil perhitungan ditunjukkan waktu dalam tiap kali pemesanan bahwa untuk merk tread Crown seharusnya memesan produk bahan baku tiap 52 hari dengan jumlah $18218 \mathrm{~kg}$, tread Naga Mas tiap 122 hari dengan jumlah 6917 $\mathrm{kg}$, tread Tiger Dingin tiap 91 hari dengan jumlah $11508 \mathrm{~kg}$, dan untuk compound (Panas) tiap 91 hari dengan jumlah $14319 \mathrm{~kg}$.

4. Dari kesimpulan diatas manajemen perusahaan perlu menerapkan teknik optimasi pada sistem produksi dan pengendalian stock nya, sehingga bisa diperoleh penghematan yang bisa dimanfaatkan untuk kebutuhan lain.

\section{Daftar Pustaka}

Assauri, Sofjan. 2004. Manajemen Produki dan Operasi, FE UI, Jakarta

Daengs, Maslikha, 2013. Sistem Pengendalian Bahan Baku, Penelitian, Surabaya, Universitas 45,

Hanafi, M. Mahmud dan Abdul Halim. 2009. Analisis Laporan Keuangan, UPP AMP YKPN, Yogyakarta

Kostas, Dervitsiotis N. 2008. Operation Management, $2^{\text {nd }}$ edition, Me Graw-Hill.

Kusuma, Hendra. 2001. Sistem Produksi, Bandung, Universitas Maranatha.

Moleong, Lexy J. 2000. Metodologi Penelitian Kuantitatif, Bandung, Penerbit Remaja Rosda Karya

Munawir. 2007. Analisa Laporan Keuangan, Yogyakarta, Liberty.

Nasution, Arman Hakim. 2003. Perencanaan dan pengendalian Produksi, Cetakan Kedua, Surabaya, Penerbit Guna Widya.

Prawirosentono, Suyadi 2007. Manajemen Operasi, Edisi Keempat, Jakarta, Penerbit PT. Bumi Aksara

Subagiyo, Pangestu, 2009. Manajemen Operasi, Edisi Pertama, Yogyakarta, BPFE. 
Sudana, Made I. 2011. Manajemen Keuangan Perusahaan Teori dan Praktik, Penerbit Erlangga

Sugiyono. 2012. Statistika Untuk Penelitian, Penerbit Alfabeta.

Sumarsan, Thomas. 2010. Sistem Pengendalian Manajemen, Cetakan pertama, Jakarta, Penerbit PT. Indeks.

Sunyoto, Danang, 2011. Manajemen Operasional, Yogyakarta, Caps.

Randar, Barry; Hayzar Jay, 2001. Prinsip-Prinsip Manajemen Operasional, edisi. 1, Jakarta, Salemba 4. 